\title{
Structural and microstructural regularities and factor analysis of the distribution of diamonds in metamorphic rocks of the Kokchetav Massif, Northern Kazakhstan, as evidence of their in-situ metasomatic origin from gaseous phase
}

\author{
Victor A. Pechnikov ${ }^{1}$ and Felix V. Kaminsky ${ }^{2}$ \\ ${ }^{1}$ Central Research Institute of Geological Prospecting for Base and Precious Metals (TsNIGRI), 129-1 \\ Varshavskoe shosse Moscow, 117545, Russia \\ ${ }^{2}$ KM Diamond Exploration Ltd., 2446 Shadbolt Lane, West Vancouver, BC, V7S 3J1, Canada
}

The Kumdy-Kol deposit and the Barch-Kol occurrence in the Kokchetav Massif, Northern Kazakhstan are unique for their diamond potential which exceeds 2,500 million carats and grade.

\section{Structure of diamondiferous zones in metamorphic rocks}

Diamond contents in metamorphic rocks within the Kumdy-Kol deposit vary widely, from below one to several hundred carats per ton (cpt). Diamonds exist in almost all types of rocks in these two areas, and there is no lithological control in the diamond distribution. Diamond-rich zones follow a linear branched pattern of metasomatic rocks developed along NNE-trending faults (Fig. 1).

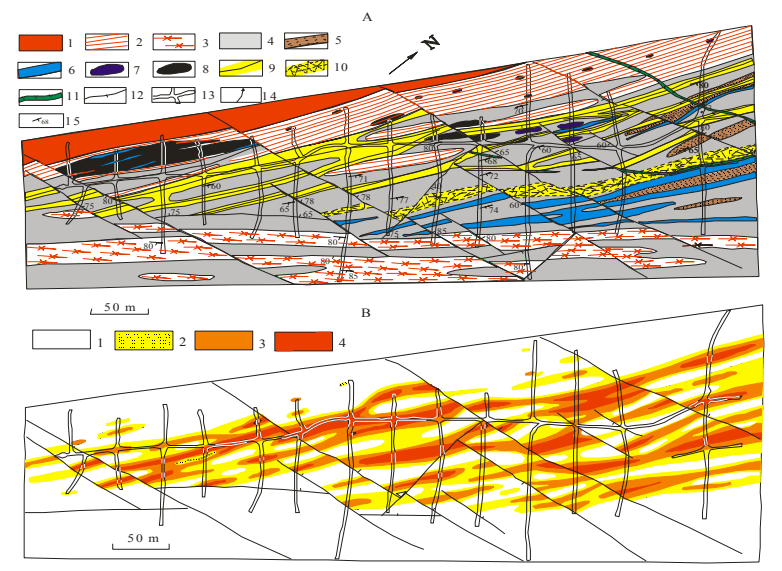

Fig. 1. Geology of diamondiferous zone (top) and distribution of diamond grade (bottom) in the KumdyKol deposit. A: 1 - garnet-muscovite leucocratic granite, 2 - 'transition zone', 3 - migmatite, 4 - garnetbiotite and biotite gneiss, 5 - quartzose rock, 6 siliceous-carbonate rock, 7 - eclogite, 8 - garnetpyroxene rock. Fault-related metasomatites: 9 - related to NE-trending zones, 10 - related to the fissure zones. 11 - dyke of dioritic porphirite, 12 - minor faults, 13 adit horizon, 14 - drillholes, 15 - strike and dip of foliation. B: diamond grade (in cpt): 1 - from 0 to 5,2 - from 5 to 20,3 - from 20 to 50,4 - more than 50 .

The thickness of metasomatic bodies ranges from several meters to several tens of meters. NNE-trending faults form a system closely related to diamondiferous metasomatites. Their thickness ranges from 0.2 to $1.5-$ $2.0 \mathrm{~m}$. The fault zones consist of brecciated metasomatite with cryptocrystalline graphite.

The Barchi-Kol diamond occurrence is geologically similar to the Kumdy-Kol deposit. Gneiss varieties dominate among the rocks (garnet-biotite, biotite, kyanite, and zoisite with numerous lenses of silicatecarbonate and garnet-pyroxene rocks; subordinate eclogite and amphibolite bodies). Several linear diamondiferous zones trend NE and follow the general strike of the metamorphic rocks. The diamond distribution within the Barchi-Kol is uneven, with grades of several tens of carats per one ton. Generally, diamond mineralization here is less concentrated than in Kumdy-Kol. Several rock types were specified within the Barchi-Kol: gneiss, micro-gneiss, siliceouscarbonate rocks, etc.

Like in the Kumdy-Kol deposit, gneisses in the BarchiKil occurrence are major diamondiferous rocks. Their major mineral assemblage consists of garnet-mica, kyanite, and zoisite varieties. Garnet-mica gneiss consists of garnet (pyrope-almandine, with minor grossular), biotite, and quartz-feldspar aggregates with varying amounts of graphite and sulfides, occasionally containing amphibole and phlogopite. Biotite-zoisite gneiss occurs only in the Barchi-Kol deposit, being unknown in Kumdy-Kol.

\section{Diamond distribution control: Factor analysis}

Geological observations on the structural control of diamondiferous zones and the associated metasomatites have been tested both in the Kumdy-Kol and the Barchi-Kol areas with the use of the factor analysis. The key objective of the analysis was to reveal the factors responsible for diamond potential of the rocks. Gneiss has been chosen as the main object of study because it is the most common diamondiferous rock variety carrying $c a .80 \%$ of diamonds within the Kokchetav Massif. Gneiss displays both structural and textural, as well as mineral composition signatures which mirror polygenic processes. Every sample was analyzed for its diamond grade (using caustic fusion) 
and major element composition. Data obtained for the diamond grade are in agreement with the detailed sampling results previously carried out at Kumdy-Kol.

Statgraf software was used to carry out factor analysis of the data. To obtain a more simple structure of the factor loading matrix, the Varimax rotation method was employed.

As a result, the following gneiss varieties were distinguished within the general population: ferruginous (garnet-biotite), hydrated and graphitized (Factor 1), carbonatized (Factor 2), aluminous, after clay rocks (Factor 3), and ferruginous (garnet-biotite), developed predominately after arenaceous rocks (Factor 4). Fig. 2 represents a correlation matrix projected onto the Factor 1 - Factor 2 plane; these two factors are responsible for $56 \%$ of total variability.

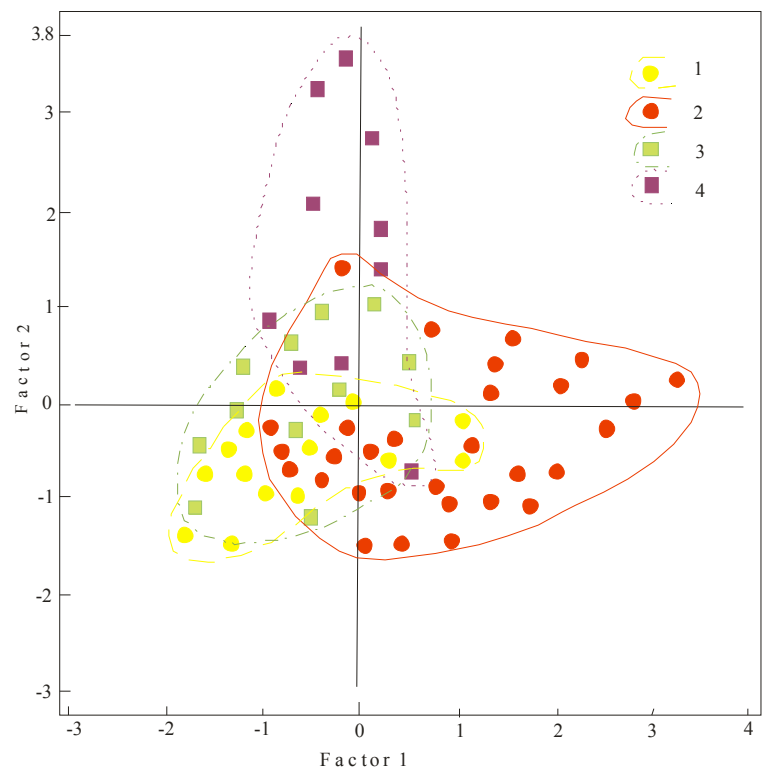

Fig. 2. Figurative points of diamondiferous (red and purple) and barren (yellow and green) samples from the Kumdy-Kol deposit and the Barchi-Kol occurrence.

Factor 1 influences several positively correlated components $\left(\mathrm{Fe}_{2} \mathrm{O}_{3}, \mathrm{P}_{2} \mathrm{O}_{5}, \mathrm{TiO}_{2}, \mathrm{H}_{2} \mathrm{O}, \mathrm{S}\right.$ и $\left.\mathrm{C}\right)$. Factor 2 reflects low-contrast carbonatization $(\mathrm{CaO}, \mathrm{MgO}$ and $\mathrm{CO}_{2}$ ). Consequently, Factor 1 and Factor 2 characterize processes with essential participation of volatiles $\left(\mathrm{H}_{2} \mathrm{O}\right.$ in the case of the former and $\mathrm{CO}_{2}$ in the latter one)..

Data points of barren samples form two sub-isometric fields which overlap at the origin, i.e., at the area of minimum values of both factors. On the contrary, the data points of diamondiferous samples form two elongated fields oriented along the factor axes: the Kumdy-Kol points (red) follow the Factor 1 axis, and the Barchi-Kol points (purple) follow the Factor 2 axis. Thus, Factor 1 is critical in the Kumdy-Kol diamond potential and Factor 2 in the Barchi-Kol case. This indicates the role of different volatiles: the Kumdy-Kol fluids were predominately hydrous, carrying minor amounts of $\mathrm{CO}_{2}$, whereas the Barchi-Kol fluids were rich in $\mathrm{CO}_{2}$. This conclusion well corresponds to geological data: in Kumdy-Kol the hydration of gneiss takes place, while in Barchi-Kol carbonatization occurs.

\section{Distribution of diamonds in rock-forming minerals}

Both grains of rock-forming minerals and intergranular voids host diamond crystals. Diamonds were found in biotite and quartz from garnet-biotite gneiss, in a chlorite-tremolite-actinolite matrix of quartzose rocks, in hornfels from pyroxene-amphibole-feldsparquartz varieties, as well as in clinopyroxene, garnet, and phlogopite from pyroxene-phlogopite-carbonate rocks. Relatively large $(200-300 \mu \mathrm{m})$ crystals were found in the inter-granular space of garnet-pyroxene rocks in quartz-feldspar aggregates, as well as in the fissure-filling carbonates. Graphite, clinopyroxene, rutile, titanite, kyanite, KFS, biotite, phengite, and carbonates are on the list of minerals forming intergrowths with diamonds.

Fig. 3 of garnet-biotite gneiss from the Kumdi-Kol deposit shows a diamond microcrystal intergrowing within a newly-formed grain of a carbonate mineral, which does not replace a pre-existing mineral but fills the voids in a micro-fissure.

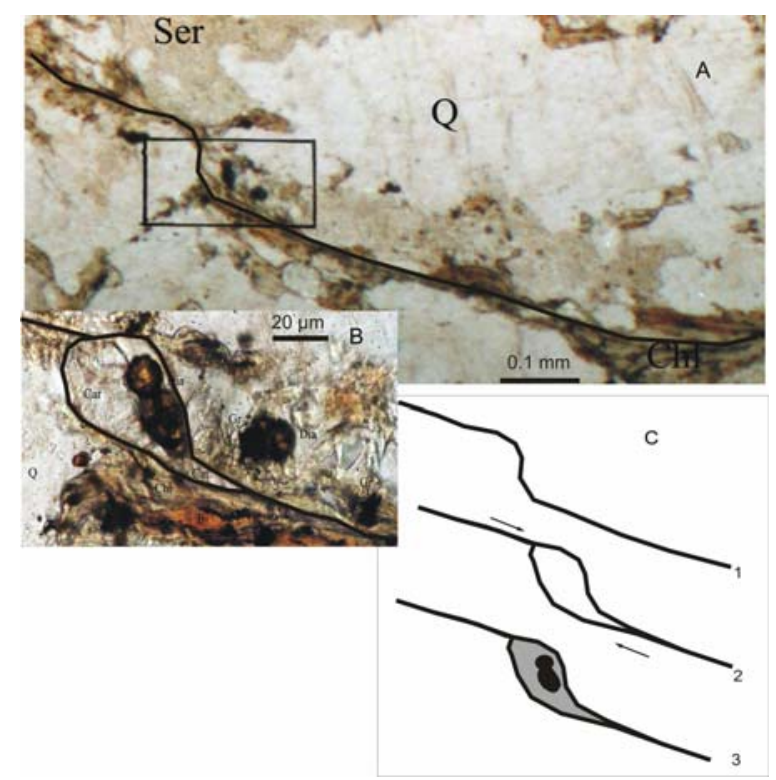

Fig. 3. Microphotographs (A and B) and interpretation (C) of diamond formation in a carbonate matrix. Three stages can be distinguished for the formation of this structure: 1 - development of a sigmoid micro-fissure; 2 - formation of a micro-shift with the development of a void along a fissure; 3 - deposition of carbonate with micro-inclusions of diamond within the void; along the major fissure chlorite-sericite aggregate develops, and chlorite locally replaces biotite. The mineral deposition sequence shows that carbonate and diamond are younger than the hosting minerals composing garnetbiotite gneiss. 


\section{Discussion and conclusions}

Geological data obtained from the detailed prospecting of the Kumdy-Kol deposit and the Barchi-Kol occurrence indicate that diamond mineralization in the metamorphic rocks of the Kokchetav Massif is neither controlled by a special rock type(s), nor by its random spatial distribution, as could be expected from the UHP nature of the parent process. Diamondiferous zones, especially those of a potentially economic grade, form linear patterns which follow NNE-striking tectonic zones. These zones host metasomatic rocks developed after all varieties of regionally metamorphosed (amphibolite facies) rocks with the most contrast revealed in a gneissose substrate. In Kumdy-Kol, metasomatites at the fault zones occur as intensely chloritized and sericitized blastomylonite with relics of metamorphic rocks. At the Barchi-Kil occurrence, these are predominately strongly carbonatized varieties.

Results of the factor analysis confirm relationship of diamond with metasomatites. As demonstrated, factors typical of metasomatic processes simultaneously characterize diamond potential (both in the Kumdy-Kol deposit and in the Barchi-Kol occurrence). Our data indicated that chemically different fluids had caused metasomatic alterations in these areas. The Kumdy-Kol fluids were predominately hydrous, carrying minor amounts of $\mathrm{CO}_{2}$, whereas the Barchi-Kol fluids were rich in $\mathrm{CO}_{2}$. In the case of the former, it resulted in the hydration of gneiss, whereas in the latter carbonatization occurred.

Crystallization of diamonds from a fluid phase has been convincingly demonstrated by studies of fluid inclusions from kimberlites where it occurs at sufficiently high temperature and pressure. At normal atmospheric pressure conditions this mechanism is widely used in the CVD synthesis employed by jewelry. Nanocrystalline diamonds were found in highdensity $\mathrm{CO}_{2}\left(+\mathrm{H}_{2} \mathrm{O}+\mathrm{H}_{2} \mathrm{~S}\right)$ fluid inclusions in garnet pyroxenites from the Salt Lake Crater near Oahu, Hawaii. Epitaxial diamond inclusions were found to occur in rubies from Vietnam. Diamond forms intergrowths with oxides of Ti, Al, Fe and Fe-Cr-Ni-F, which indicates its crystallization from the gaseous $\mathrm{CO}_{2}$-bearing phase captured into rubies at low PT conditions. A similar process caused the formation of diamonds in metamorphic rocks of the Kokchetav Massif.

\section{References}

Dobrzhinetskaya, L.F., Braun, T. V., Sheshkel, G.G., Podkuiko, Y.A., 1994. Geology and structure of diamond-bearing rocks of the Kokchetav Massif, Kazakhstan. Tectonophysics 233, 293-313

Ekimova, T.E., Lavrova, L.D., Petrova, M.A., 1992. Diamond inclusions in rock-forming minerals of the metamorphic rocks. Doklady Academii Nauk SSSR 322,
366-368 (in Russian)

Frezzotti, M.-L., Peccerillo, A., 2007. Diamond-bearing COHS fluids in the mantle beneath Hawaii. Earth and Planetary Science Letters 262, 273-283.

Korsakov, A.V., Shatsky, V.S., Sobolev, N.V., Zayachokovsky, A.A., 2002. Garnet-biotite-clinozoisite gneiss: a new type of diamondiferous metamorphic rock from the Kokchetav Massif. European Journal of Mineralogy, 14, 915-928.

Lavrova, L.D., Pechnikov, V.A., Petrova, M.A., Zayachkovsky, A.A., 1996. Geology of the Barchi diamondiferous area. Otechestvennaya Geologiya, no. 12, 20-27 (in Russian).

Lavrova, L.D., Pechnikov, V.A., Pleshakov, A.M., Nadezhdina, E.D., Shukolyukov, Yu.A., 1999. A new genetic type of diamond deposit. Scientific World Publishing House, Moscow, 228 p. (in Russian).

Navon, O., 1999. Diamond formation in the Earth's mantle. In: Gurney, J.J., Gurney, J.L., Pascoe, M.D., Richardson, S.H. (Eds), Proceedings of the VIIth Internat Kimberlite Conference, vol. 2. Red Roof Design, Cape Town, 584-604.

Ogasawara, Y., Ohta, M., Fakasawa, K., Katayama, I., Maruyama, S., 2000. Diamond-bearing and diamondfree metacarbonate rocks from Kumdy-Kol in the Kokchetav Massif, northern Kazakhstan. Island Arc, 9 (3), 400-416

Park, G.-S., Bae, S.C., Granick, S., Lee, J.-H., Bae, S.D., Kim, T., Zuo, J.M., 2007. Naturally formed epitaxial diamond crystals in rubies. Diamond and Related Materials, 16, 397-400.

Pechnikov, V.A., 1993. Peculiarities of localization of diamond manifestations in metamorphic rocks. Razvedka i Okhrana Nedr, no. 4, 11-14 (in Russian).

Pechnikov, V.A., Ekimova, T.E., 1995. The origin of microdiamond deposits in metamorphic complexes. In: Mineral Deposits: From Their Origin to Their Environmental Impacts, J. Passava., B. Kribek and K. Zak, eds., A.A. Balkema. Rotterdam, 621-624.

Pechnikov, V.A., Kaminsky, F.V., 2008. Diamond Potential of Metamorphic Rocks in the Kokchetav Massif, Northern Kazakhstan. European Journal of Mineralogy. $20(3)$.

Shatsky, V.S., Sobolev, N.V., Vavilov, M.A., 1995. Diamond-bearing metamorphic rocks of the Kokchetav massif (Northern Kazakhstan). In: Coleman, R.G., Wang, X. (Eds.), Ultrahigh-Pressure Metamorphism, Cambridge University Press, Cambridge, 427-455.

Shatsky, V.S., Sitnikova, E.S., Koz'menko, O.A., Nikolaeva, I.V., Zayachkovsky, A.A., 2006. Behavior of incompatible elements during ultrahigh- pressure metamorphism (by the example of rocks of the Kokchetav massif). Geologiya i Geofizika (Russian Geology and Geophisics), 47 (4), 485-498 (482-496).

Sobolev N.V., Shatsky V.S., 1990. Diamond inclusions in garnets from metamorphic rocks: a new environment for diamond formation. Nature, 343 (6260), 742-746. 